\title{
RAD9B Gene
}

National Cancer Institute

\section{Source}

National Cancer Institute. RAD9B Gene. NCI Thesaurus. Code C106280.

This gene is involved in both DNA repair and cell cycle progression. 